\title{
CHANGES IN SENSITIVITY TO CONVULSION IN MICE WITH OLFACTORY BULB ABLATION
}

\author{
Yasunori ARAKI and Showa UEKI \\ Department of Pharmacology, faculty of Phamaceutical Sciences, \\ Kyushu University. Fukuoka, Japan
}

Received for publication December 9, 1971

Since bilateral ablations of the olfactory bulb were found to induce characteristic hyperemotionality in the rat (1-5), this bchavior, parlicularly aggressiveness, has come to be used for evaluating the taming effect of tranquilizing agents, though the neural mechanisms underlying this abnormal behavior have remained unknown (6).

It would be worthwhile to know the changes in drug sensitivity of such abnormal animals, even from the ceinical point of view, and the effects of psychotropic drugs are known to be different qualitatively, as well as quantitatively, depending on the disease.

Studies concerning the changes in drug sensilivity in abnormal animals with such brain lesions have so far been few (7-11). Recently, Malick et al. (12) compared the effeets of psychoactive agents on three models of aggression induced by lesioning of the septum, the ventromedial hypothalamus and the olfactory bulb in rats, and found significant differences in potencies of these drugs among these models with lesions in different brain areas. Questions may arise as to whether or not these potency differences are also relevant to effects other than anti-aggressive action, and as to whether the drug sensitivities of these models are different from that of intact animals, as aggressiveness is rarely observed in nomal laboratory rats.

This investigation was therefore underaken to determine changes, if any, in sentisivity to clectroshock- and drug-induced convulsions in mice with bilateral olfactory bulb ablations, since convulsions could be measured quantitatively and compared between the intact and ahnormal animals with brain lesions.

\section{METHODS}

Animals: Male CF $\$ 1$ mice, weighing between 20 and $28 \mathrm{~g}$ at the time of surgery, were employed in this experiment.

Surgery: The olfactory bulbs were bilaterally removed by suction through an opening mode in the skull just above the bulb under pentobarbital anaethesia. In the sham operated group, the same surgical procedure was performed without the ablation of the olfactory bulbs. The animals were given penicillin 30,000 units s.c, after surgery, housed in groups

This investigation was supported by the rescarch grant from the Japanese Ministry of Education, and partly by Takeda Science Foundation. 
of 5 to 6 mice, and given water and lood at libitum. Experiments were started 2 weeks afier the surgery. After temination of the experiments, the brain was perfused through a canuk in the heart with physiokngical saline followed by $10_{0}^{\circ}$ formalin and extracted from the skull. The extent of the offictory butb lesion was examined macroscopically, and then the brain was sectioncd and stained with cresyl violet. Under the microscope, the olfictory bulhs and surrounding lissues were examined histologically. The mice with olfactory bulb ablation (O.B. mice), in which more than 1/3 of both the butbs remained, or injuries in the forchrain existed, were excluded from the data. In the sham operated group. the mice which cxhibited ditmage to the olfactory hulb were also discarded.

Fxperimintal proccilues: The develupments of electroshock- and drug-induced convulsions were observed in each group.

1) Maximal dectroshock siture tist (M.F.S.)

Electroshock of $50 \mathrm{~mA}, 60 \mathrm{c} / \mathrm{s}$ a.c., generated by a partly modified Woodbury and Davenport's apparatus (13), was applied to the head through the corneal electrodes (14) for $0.2 \mathrm{sec}$ in micc, and the time courses of the tonic flexion (TF), tonic extension (TE), clonic convulsion (CL) and postictal coma (CO) were measured in sec. (15). Running movements (RM) were included in CL. Ciroups of Iwenty mice were used in this experiment.

2) Minimal elcotroshock threshold test (M.E.T.)

By changing the intensity of electroshock current stepwise, the threshold intensity for inducing convulsion was measured and the 50\% convulsant current (CS50) was calculated. As indices of the convulsion, minimal full seizure (MS), RM, CL. TF and TE were observed (16). Twenty four mice were used in cach group.

3) Drus-induced convulsion

The convulsions induced by suhcutaneous injection of pentetrazol, picrotoxin, aminohexan (1-chyl-benzoxy-2-dimethylaminomethyl-cyclohexane) and strychnine nitrate in the O.B. mice were compared with those in the intact mice. The $50 \%$ convulsant dose (CD50) for cach drug was determined in cach group. Fight mice were used for each dose of the drugs in this experiment.

4) Statistical analysis

The data were statistically analyzed by the method of Litchfield and Wilcoxon (17)

\section{RESULTS}

Maximal clectroshock conwlsion (M.E.S.)

The development of the maximal electroshock convulsion in the O.B. mice was gualitatively similar to that in the intact mice, but the time course of the convulsion was different in some respects as shown in Fig. 1. The durations of TF and TE in the O.B. mice were almost the same as in the intact mice. Those of $C L$ and $C O$ were 7 and $70 \mathrm{sec}$ in average respectively in the intact mice, whereas they were markedly reduced to 4.4 and $25.5 \mathrm{sec}$. respectively in the $O$. B. mice. The time course of the convulsion in the sham operated mice was cxactly same as in the intact group. 


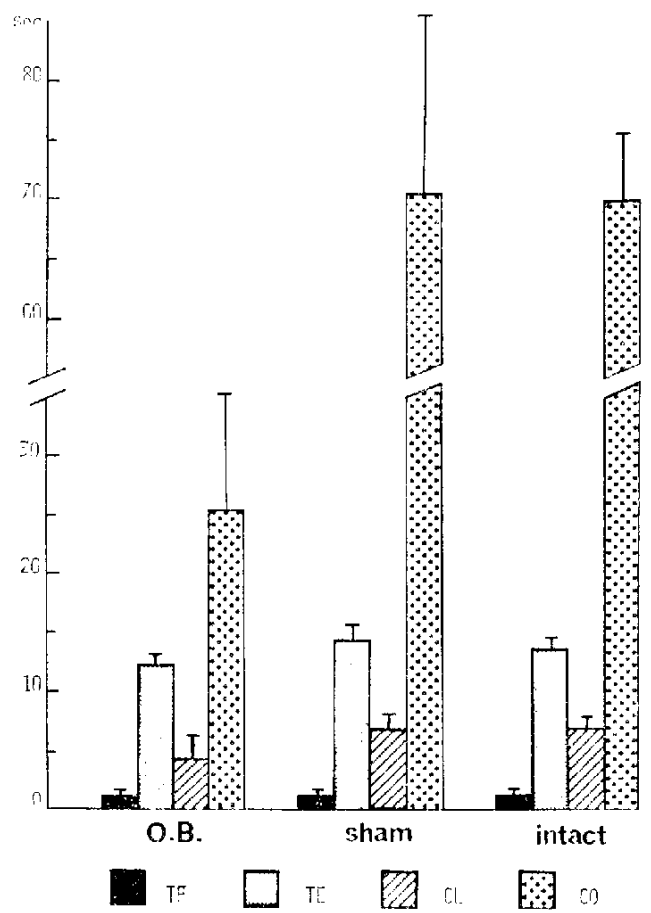

Fig. 1. A comparison of the maximal clectroshock seizure in the intact, shamoperated and O.B. mice. Abscissa indicates the duration of ennulsion or coma in seconds.

TF : tonic flexion, TE : tonic extension,

CL : clonic convulsion, CO : postictal coma

\section{Minimal dectroshock threshold (M.E.T.)}

The threshoid currents for inducing minimal full seizure in the intact, sham operated and O.B. mice are illeistrated in Fig. 2. Though the threshold in the sham operated group was not significantly different from that of the intact group, that in the O.B. mice was much higher than in the other groups $(\mathrm{p}<0.01)$. The CS50 was $7.1(5.6-8.9) \mathrm{mA}$ for the intact, 7.6 (6.8-8.4) $\mathrm{mA}$ for the sham operated and $13.5(10.8 \cdot 16.9) \mathrm{mA}$ for the O.B. mice.

\section{Pentetrazol convulsion}

The incidences of MS, CL and TE induced by various subcutancous doses of pentetrazol in the intact, sham operated and O.B. groups of each eight mice are shown in Table 1. The total incidence of convulsion in the O.B. mice was not significanlly different from that in the intact or sham operated group, though CL was more marked and longer-lasting when induced in the O.B. mice. The incidence of TE in the O.B. mice, however, was slightly lower than that in the other groups, and, therefore, the number of deaths following TE was slightly reduced in the O.B. mice, though the I.D5i) wals not significantly different from that in the intact group.

\section{Picrotoxin conulsion}

As can be seen in Table 2, the incidences of MS and $\mathrm{Cl}$. induced by picrotoxin in the 


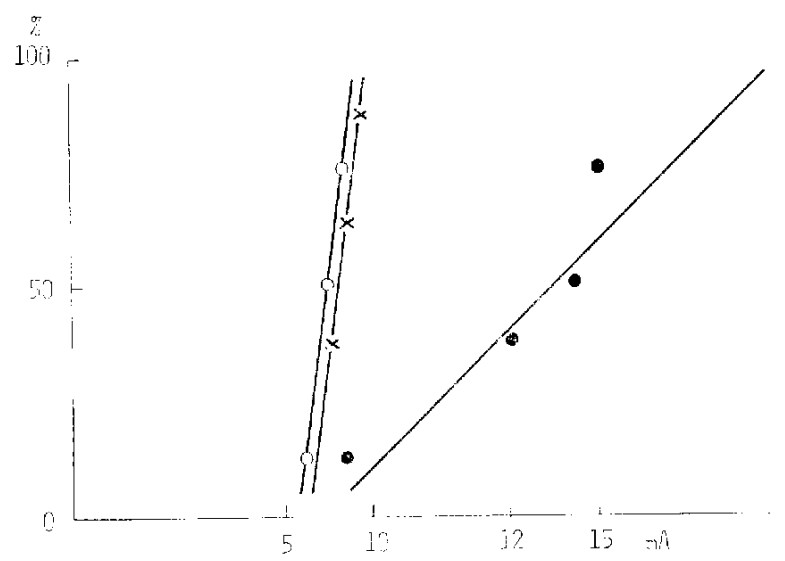

Fici. 2. Changes in the minimal electroshock threshold after bilateral ablations of the O.B. mice. (dose-response curve)

(i) intact mice, : O.B. mice, $x$ : sham-operated mice.

TABI.F. 1. Incidence of pentetrazol convulsion in the intact, sham operated and O.B. mice.

\begin{tabular}{|c|c|c|c|c|c|c|c|c|c|c|c|c|c|c|c|}
\hline \multirow{3}{*}{$\begin{array}{c}\text { Dose } \\
\text { (mgkg s.c.) }\end{array}$} & \multicolumn{5}{|c|}{ Intact } & \multicolumn{5}{|c|}{ Sham } & \multicolumn{5}{|c|}{ O.B. } \\
\hline & \multicolumn{4}{|c|}{ Convulsion } & \multirow{2}{*}{ Death } & \multicolumn{4}{|c|}{ Convulsion } & \multirow{2}{*}{ Death } & \multicolumn{4}{|c|}{ Convulsion } & \multirow{2}{*}{ Death } \\
\hline & MS & $C L$ & TE & Total & & MS & CL & TE & Total & & MS & $\mathrm{CL}$ & TE & Total & \\
\hline 50 & 0 & 1 & 0 & 1 & 0 & 0 & 2 & 0 & 2 & 0 & 0 & 1 & 0 & 1 & 0 \\
\hline 6) & 0 & 2 & 1 & 3 & l & 0 & 4 & 0 & 4 & 0 & 1 & 3 & 0 & 4 & 0 \\
\hline 70 & 1 & 4 & 1 & 6 & 1 & 0 & 6 & 1 & 7 & 1 & 0 & 4 & 1 & 5 & 1 \\
\hline 85 & 0 & 3 & 5 & 8 & 5 & 0 & 3 & 5 & 8 & 5 & 0 & 4 & 3 & 7 & 3 \\
\hline 100 & 0 & 0 & 8 & 8 & 8 & 0 & 0 & 8 & 8 & 8 & 0) & 0 & 6 & 6 & 6 \\
\hline 120 & $\cdots$ & -. & - & - & -- & - & -- & - & - & -- & 0 & 0 & 8 & 8 & 8 \\
\hline $\begin{array}{l}\text { CJ) } 50(95 \% \\
\text { confidence } \\
\text { limils) }\end{array}$ & 62. & $0 \quad 5$ & 6.06 & $64.2) \mathrm{I}$ & $\mathrm{mg} \mathrm{kg}$ & 58.0 & $0<5$ & $2.3 \mathrm{C}$ & $84,4)$ & $\mathrm{mg} / \mathrm{kg}$ & 64. & .016 & $0.3-$ & 67.8) & $\mathrm{mg} / \mathrm{kg}$ \\
\hline $\begin{array}{l}\text { LD } 50\left(95^{\circ}\right. \\
\text { confidence } \\
\text { limits) }\end{array}$ & 78. & $0<6$ & $6.7-8$ & $88.9) 1$ & $m g i k g$ & 78.1 & $0<6$ & $6.7-8$ & $88.9)$ & mgkg & 90. & $.0(7$ & 9.0 & $100.2)$ & $m g / k g$ \\
\hline
\end{tabular}

$\mathrm{N}$..8, intact : intact mice, sham : sham-operated mice, O.B.: mice with bilateral olfactory bulb ablation, MS : minimal full seizure, $\mathrm{CL}$ : clonic convulsion (running movements are also includat), TF : tonic convusion, total incidence of convulsion, Albreviations are the same in the following tables.

O.B. mice were almost the same as in the intact mice, while that of TE was slightly lower and thus the LD50 was a little larger than that in the intact mice, though a statistically significant difference was not found between two groups.

\section{Aminohexan convulsion}

It has been known that aminohexan induces only $\mathrm{CL}$ in mice (16). The incidence of aminohexan convulsion in the O.B. mice was less than that in the intact mice, as shown in 
TABIE: 2. Incidende of picrotoxin convulsion in the intact and O.B. mice.

\begin{tabular}{|c|c|c|c|c|c|c|c|c|c|c|}
\hline \multirow{3}{*}{$\begin{array}{c}\text { Dose } \\
\text { (mgikg s.c.) }\end{array}$} & \multicolumn{5}{|c|}{ Intact } & \multicolumn{5}{|c|}{ O.B. } \\
\hline & \multicolumn{4}{|c|}{ Convulsion } & \multirow{2}{*}{ Death } & \multicolumn{4}{|c|}{ Convulsion } & \multirow{2}{*}{ Death } \\
\hline & MS & $\mathrm{CL}$ & TE & Total & & MS & $\mathrm{CL}$ & TE: & Total & \\
\hline 0.7 & 3 & 0 & () & 3 & 0 & 2 & 0 & 0 & 2 & 0 \\
\hline 1.0 & 3 & 2 & 0 & 5 & 0 & 2 & 2 & 0 & 4 & 0 \\
\hline 2.0 & 2 & 4 & 0 & 6 & 0 & 2 & 4 & 0 & 6 & 0 \\
\hline 2.5 & 0 & 4 & 4 & 8 & 4 & 0 & 6 & 2 & 8 & 2 \\
\hline 2.7 & 0 & 2 & 6 & 8 & 6 & 0 & 3 & 5 & 8 & 5 \\
\hline 3.0 & 0 & 0 & 8 & 8 & 8 & 0 & 2 & 6 & 8 & 6 \\
\hline 5.0 & 0 & 0 & 8 & 8 & 8 & 0 & 0 & 8 & 8 & 8 \\
\hline $\begin{array}{l}\text { CD } 50 \text { (95\% } \\
\text { confidence } \\
\text { limits) }\end{array}$ & \multicolumn{5}{|c|}{$1.0(0.61-1.31) \mathrm{mg} / \mathrm{kg}$} & \multicolumn{5}{|c|}{$1.1(0.72-1.50) \mathrm{mg} / \mathrm{kg}$} \\
\hline $\begin{array}{l}\text { LD } 50(95 \% \\
\text { confidence } \\
\text { limits) }\end{array}$ & \multicolumn{5}{|c|}{$2.5(2.20-2.72) \mathrm{mg} / \mathrm{kg}$} & \multicolumn{5}{|c|}{$2.7(2.50-2.92) \mathrm{mg} / \mathrm{kg}$} \\
\hline
\end{tabular}

TABLF. 3. Incidence aminohexan convulsion in the intact and O.B. mice.

\begin{tabular}{|c|c|c|c|c|c|c|c|c|c|c|c|}
\hline \multirow{3}{*}{ (mgkg s.c.) } & \multicolumn{6}{|c|}{ Intact } & \multicolumn{5}{|c|}{ O.B. } \\
\hline & \multicolumn{4}{|c|}{ Convulsion } & & \multirow{2}{*}{ Death } & \multicolumn{4}{|c|}{ Convulsion } & \multirow{2}{*}{ Death } \\
\hline & MS & $C L$ & TE & Total & & & MS & CL & $\mathrm{TE}$ & Total & \\
\hline 120 & 0 & 1 & 0 & 1 & & 0 & -. & $\ldots$ & -- & $\ldots$ & -- \\
\hline 150 & 0 & 4 & 0 & 4 & & 0 & 0 & 0 & 0 & 0 & 0 \\
\hline $2 n !$ & 0 & 6 & 0 & 6 & & 2 & 0 & 3 & 0 & 3 & 0 \\
\hline $22 !$ & 0 & 8 & 0 & 8 & & 3 & 0 & 4 & 0 & 4 & 1 \\
\hline 259 & 0 & 8 & 0 & 8 & & 6 & 0 & 6 & 0 & 6 & 2 \\
\hline 270 & -- & $\cdots$ & & & & & 0 & 8 & 0 & 8 & 4 \\
\hline 300 & & & - & $\cdots$ & & & 0 & 8 & 0 & 8 & 6 \\
\hline $\begin{array}{l}\text { CD } 50\left(95^{\circ}\right. \\
\text { confidence } \\
\text { limits) }\end{array}$ & \multicolumn{6}{|c|}{$158.0(143.2171 .8) \mathrm{mg} / \mathrm{kg}$} & \multicolumn{5}{|c|}{$215.0(186.1245 .4) \mathrm{mg} \cdot \mathrm{kg}^{* * *}$} \\
\hline $\begin{array}{l}\text { LD } 50 \quad 95 \% \\
\text { confidence } \\
\text { imils) }\end{array}$ & \multicolumn{6}{|c|}{$233.0(212.0257 .2) \mathrm{mg} / \mathrm{kg}$} & \multicolumn{5}{|c|}{$272.0(251.9-293.8) \mathrm{mg} / \mathrm{kg}^{*}$} \\
\hline
\end{tabular}

Table 3, i.e. the CD50 tor the O.B. mice was significantly greater $(p<0.01)$ than that for the intact mice. In the O.R. mice, aminohexan caused neither behavioral changes nor convulsion in doses less than $150 \mathrm{mg} / \mathrm{kg}$ s.c. When CL, was induced by aminohexan in doses higher than $200 \mathrm{mg} / \mathrm{kg}$ s.c. in the O.B. mice, it was more intense and longer-lasting. The LD50 of aminohexan for the O.B. mice was sisnificantly greater than that for the intact mice $(\mathrm{p}, 0.05)$. 
Stryctuine convtrsion

The convulsion induced by various subcutancous doses of strychnine is shown in Table 4. Strychnine caused some motor exiciation without inducing convulsion in doses less than $0.5 \mathrm{mg} / \mathrm{kg}$ s.c., but the drug induced TE: within $10 \mathrm{~min}$. in doses over $0.7 \mathrm{mg} / \mathrm{kg}$ s.c. and TF: was invariably followed by death in the intact nice. However, more than $1.0 \mathrm{mg} / \mathrm{kg}$ of the drug was needed to induce convulsion in the O.B. mice, and, furthermore, some of the animals cshibited only CL instead of TE, and some induced long-lasting CL before the development of TE. Such a convulsion pattern was never observed with strychnine in the intact mice. The LD50 of strychnine for the O.B. mice was thus significantly greater $(p<0.01)$ than that for the intact mice.

TABLF 4. Incidence of strychnine convulsion in the intact and O.B. mice.

\begin{tabular}{|c|c|c|c|c|c|c|c|c|c|c|}
\hline \multirow{3}{*}{$\begin{array}{c}\text { Dose } \\
\text { (ng/kg s.c.) }\end{array}$} & \multicolumn{5}{|c|}{ Intact } & \multicolumn{5}{|c|}{ O.B. } \\
\hline & \multicolumn{4}{|c|}{ Convulsion } & \multirow{2}{*}{ Death } & \multicolumn{4}{|c|}{ Convulsion } & \multirow{2}{*}{ Death } \\
\hline & MS & $\mathrm{CL}$ & TE & Total & & MS & $C L$ & TE & Total & \\
\hline 0.5 & 0 & 0 & 0 & 0 & 0 & 0 & 0 & 0 & 0 & 0 \\
\hline 0.7 & 0 & 0 & 2 & 2 & 2 & 0 & 0 & 0 & 0 & 0 \\
\hline 1.0 & 0 & 0 & 5 & 5 & 5 & 0 & 0 & 2 & 2 & 2 \\
\hline 1.2 & 0 & 0 & 6 & 6 & 6 & 0 & 1 & 3 & 4 & 3 \\
\hline 1.5 & 0 & 0 & 8 & 8 & 8 & 0 & 2 & 4 & 6 & 4 \\
\hline 1.7 & & -- & - & & -- & 0 & 0 & 6 & 6 & 6 \\
\hline 2.0 & 0 & 0 & 8 & 8 & 8 & 0 & 0 & 8 & 8 & 8 \\
\hline $\begin{array}{l}\text { CD } 50(95 \% \\
\text { confidence } \\
\text { limits) }\end{array}$ & \multicolumn{5}{|c|}{$0.9(0.731 .09) \mathrm{m} / \mathrm{g} / \mathrm{kg}$} & \multicolumn{5}{|c|}{$1.2(0.981 .51) \mathrm{mg} / \mathrm{kg}$} \\
\hline $\begin{array}{l}\text { LD } 50(95 \% \\
\text { confidence } \\
\text { limits) }\end{array}$ & \multicolumn{5}{|c|}{$0.9(0.73-1.09) \mathrm{mg} / \mathrm{kg}$} & \multicolumn{5}{|c|}{$1.4(1.141 .70) \mathrm{mg} / \mathrm{kg}^{* *}$} \\
\hline
\end{tabular}

\section{DISCUSSION}

In the present experiments, it has been observed that mice exhibited significant behavioral changes following bilateral ablations of the olfactory bulb. Locomotor activity of the mice increased markedly even in a ordinary cage, and emotional responses to various stimuli, such as touching, pinching or handling, were greally exaggerated. These behavioral changes are qualitatively similar to those of rats with olfactory bulb ablations. When housed in a group, the O.B. mice walked around in a cage alone most of the time, and frequently bit each others tails or cars. No significant difference was found, however, in the body wt. gains of the O.B. and intact mice during the experimental period. The spinal reflexes appeared facilitated in the O.B. mice.

It was found, in this experiment, that the sensitivity to convulsions induced by electroshock or central stimulants was, in general, reduced after olfactory bulb ablation. The CI, and $C O$ were significantly decreased in duration, although the TF and TE induced by 
M.E.S. did not change. This indicates that the O.B. mice develop a less severe M.E.S. convulsion, and this is also evidenced by the finding that the threshold electric current for inducing convulsion was increased in intensity after olfactory bulb albation.

On the other hand, the MS and CL induced by pentetrazol and picrotoxin in the O.B. mice were almost the same in incidence as in the intact group, but the development of TE was reduced, and thus the incidence of death tended to be reduced, though the LD50 of these drugss showed no significant diference between the O.B. and intact mice.

The development of TL: induced by strychnine was markedly depressed, and thus the LD50 was more significantly increased in the O.B. mice than in the intact group. However, some of the O.B. mice showed more severe CL without developing TE, and some exhibited long-lasting $C L$ prior to TE. These patterns of the strychnine convulsion are never observed in intact animals. The CL induced by aminohexan was also greatly reduced in the O.B. mice.

It should be emphasized that these changes in sensitivity to convulsion, as in the behavioral changes, were rather inconsistent for a week or so after ablations of the olfactory bulb.

It is hardly conceivable that either electric current through the brain or penetration of the drugs through the blood-brain barrier is reduced by olfactory bulb ablation. It is more likely that the neural mechanisms in the CNS related to development of convulsion might be somehow changed after ablation of the olfactory bulb.

It has been reported that the brain areas which play an important role in developing tonic convulsion are the reticular formation in the midbrain, the pons and the medulla (18-20). On the other hand, many investigators have suggested, from the results of pentetrazol convulsion, that the important areas for developing clonic convulsion are the cerebral motor cortex and the thalamus, particularly the thalamo-cortical reverberating circuits and related basal ganglia or their interconnections (21.24). It is assumed that ablation of the olfactory bulb must have a great influence on the activity of these neuronal systems.

The afferent fibers originating from the olfactory bulb are distributed, mainly through the lateral olfactory tract, to the anterior olfactory nuclei, the olfactory tubercle, the prepyriform cortex, the pyriform cortex and the cortical and medial amygdaloid nuclei (25-27). These limbic areas are supposed to be directly influenced by olfactory bulb ablation as a result either of the absence of the olfactory impulses or the degeneration of the olfactory afferent fibers.

Boisacd \& Callens (28), in fact, found that the excitability of the prepyriform cortex increased after removal of the olfactory bulb, and Callens et al. (29) assumed that release from the inhibitory infuences of the olfactory neurons accounted for this phenomenon. Changes in the activity of the amygdala are also evidenced by the recent finding (30) in our laboratory that the EEG activity of the amydgala was much reduced in voltage after olfactory bulb ablation in rats with chronic electrode implants. The aclivities of other limbic areas connected with the olfactory bulb, therefore, may be changed in the O.B. mice as well.

There is very little known about the role of the limbic system in the development of 
convulsion. Nakashima (16) found that, in rabbits, aminohexan convulsion was depressed by ablation of either the cerebral hemisphere or the motor cortex, whereas it was enhanced by lesion of the ventral parts of the temporal lobe including the amygdala. It is therefore suggested that the reduced sensitivity to aminohexan convulsion of the O.B. mice may be related to increased activity of the anygdala, the prepyriform cortex etc., and that the site of atction of aminohexan may be related to the limbic areas receiving the fibers from the olfactory bulb. As the sensitivity to clonic convulsion induced by pentetrazol and picroloxin was not altered by olfictory bulb ablation, the site and mechanism of action of these agents must be different from those of aminohexan.

In the O.B. mice, some parts of the anterior olfactory nuclei were also lesioned in this experiment. The fibers from these nuclei are connected with the hypothalamus and the midbrain through the medial forbrain bundle. The activity of the hypothalamus and the midbrain may also be influenced directly by olfacotry bulb ablation, as well as indirectly with altered activity of the other limbic structures such as the amygdala, the pyriform cortex, the olfactory tubercle and so on. These may also account for the increased activity and aggressiveness of the O.B. mice.

The O.B. mice are maintained at a higher arousal level, indicating increased activity of the midbrain reticular activating system, and this condition seems to reduce the susceptibility to tonic convulsion indued by strychnine. The tonic convulsion induced by maximal electroshock failed to be reduced, but recovery from the convulsion was quite rapid in the O.B. mice. This may also be duc to an increased activity of the midbrain reticular formation. These neural mechanisms shoukl be clarified in further investigations.

Recently it was found that removal of the olfactory bulb increased norepinephrine levels with clevated activity of monoamine oxidase (MAO) in the brain stem, whereas removal decreased norepinephrine with lowered MAO activity in the telencephalon (31 33 ). These changes in the brain stem catcholamines might be correlated with reduced susceptibility to convulsion in the O.B. mice. Schlesinger el al. (34), in fact. have studied a correlation between endogeneous brain levels of 5-hydroxytryptamine (5-IIT) and norepinephrine and susceptivility to aduiogenic seizure in mice, and found that lowering levels of 5-IIT and or norepinephrine, in general, enhanced seizure susceptibility, whereas increasing levels of these amines tended to protect against convulsion. Changes in brain 5-HT levels after removal of the olfactory bulb have not yet been reported. Further investigations atong this line would he necessary to elucidate the mechanism of emotional changes, as well as the mechanism of reduced susceptibility to convulsion in the O.B. mice.

\section{SUMMARY}

Changes in sensitivity to the convulsions induced by electroshock and central nervous system stimulants were investigated after bilateral ablations of the olfactory bulb in mice. The results are summarized as follows:

1. The tonic flexor and tonic extensor convulsion induced by maximal electroshock showed no significant change, but the clonic convulsion and postictal comal were markedly 
reduced in duration after ablation of the olfactory bulb,

2. The electroshock threshold intensity for inducing convulsion was significantly increased after olfactory bulb ablation.

3. The development of the clonic convulsion induced by pentetrazol and picrotoxin was not changed, but the incidence of the tonic convulsion tended to be ducreased after olfactory bulb ablation.

4. The tonic convulsion indued by strychnine was inhibited, but the clonic convulsion frequently occurred inslead and thus the LD50 of strychnine was increased in the O.B. mice.

5. The clonic convulsion induced by aminohexan was markedly inhibited and the LD50 was increased after olfactory bulb ablation.

6. It was suggested that altered activities of the limbic system, the hypothalamus and the midbrain might account for the changes in sensitivity to convulsion after ablation of the olfactory bulb.

\section{REFERENCES}

1) Wa1SON, J.B.: Psychol. Re'v. Monugr. Supply. 33, 43 (1907)

2) Vlirginfs, M. And Karl, P.: Compl. Rend. Soc. Biol. 157, 1061 (1963)

3) MYER, J.S.: J. comp. Phisiol. Psychol. 58, 112 (1964)

4) DOCglas, R.J., Isaacson, R.I. And Moss, R.L.: Physiol. Behar. 4, 379 (1969)

5) MaLick, J.B.: Physiol. Beful. 5, 679 (1970)

6) Kumadaki, N., Hıгомi, M. And Kumads, S.: Jap. J. Pikamac. 17, 659 (1967)

7) Blum, R.A., BLLM, J.S. And Chow, K.L.: Arch. Netrol. Psychiat., Chicaso 64, 685 (1950)

8) COLe, J. AND Gless, P.: J. ment. Sici. 103, 406 (1957)

9) DAvis, G.: Am. J. Physiol. 188, 619 (1957)

10) Iluvi, H.F.: Am. N.Y. Acad. Sci. 67, 712 (1957)

11) ADI.R, N.W.: J. Pharmac. exp. Thur. 134, 214 (1961)

12) Malick, J.B., Solta, R.D. And Goldilkg, V.E.: Arch. int. Pharmacolyn. Ther. 181, 459 (1969)

13) Wondbury, L.A. And Davenport, V.D.: Arch. int. Pharmacodyn. Thír. 92, 97 (1952)

14) Tanaka, K. and KaWhsakr, Y.: Jaip. J. Phumac, 6115 (1957)

15) Swinyard, L.A., Brown, W.C. And (ivodman, L.S.: J. Pharmase exp. Ther. 106, 319 (1952)

16) Nakashima, Y.: J. Yomago med. Ass. 9, 989 (1958) (In Japalese)

17) Litchiteld, J.T. and Wilcoxon, F.: J. Pharmac. exp. Ther. 96, 99 (1949)

18) Tanaka, K. ANd Mishima, O.: Jap. J. Pharmac. 3, 6 (1953)

19) Kreindler, A., Zucklrmann, E., Sieriade, M. and Chimion, D.: J. Neurophysiol, 21, 430 (1958)

20) Bergiman, F., Costin, A. and Gutha, J.: Flecroen. Neurophysiol. 15, 683 (1963)

21) Gastaut, H. And Hunitu, J.: Electroch. Nollophlysiol. 2, 263 (1950)

22) Oотsuנ, F.: Keio-Igaku 35, 901 (1958) (In Japanese)

23) UCHIJA, M.: Keio-Igaku 35, 907 (1958) (In Japanese')

24) Iwata, Y. nNo Mlkawa, J.: No to Shinkici 18, 797 (1960) (In Japaneso)

25) Al.Lt:N, W.F.: Am. J. Physiol. 128, 754 (1940)

26) Allison, A.C.: J. comp. Neurol. 98, 309 (1953)

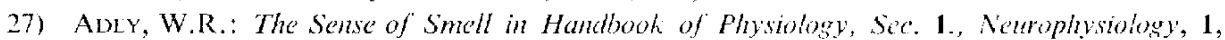
535, Am. Physiol. Soc., Washington, D.C. (1959)

28) Bolsacg-Schlplis, N. and Callens, M.: Arch. int. Physiol. Bioch. 71, 836 (1963)

29) Callens, M., Colle, J., Glrlebtzort, M.A. and Gorkaki, M.: Arch. int. Physiol. Biuch. $73,748(1965)$

30) Uhi, S., Watanabt, S., Araki, Y, and Gomita, Y. : Folia pharmac. jap. 64, 21 (1968) 
31) Pohorecky, L.A., Zigmond, M.J., Heinfr, L. ANd Wurtan, R.J.: Physiology 62, 1052 (1969)

32) Pohorecky, L.A., Lavin, F. and Wurtain, R.J.: Life Sci. 8, 1309 (1969)

33) Pohorecky, L.A. and Chalmers, J.P.: Life Sci. 10, 985 (1971)

34) Scillisinger, K., Boggan, W. and Freldiman, D.X.: Life Sci. 9, 721 (1970) 